\title{
Fishery and the Tourism Potential of Agbokum Waterfalls, Nigeria
}

\author{
Gabriel Ujong Ikpi, Benedict Obeten Offem \\ Department of Fisheries and Aquatic Science, Cross River University of Technology, Obubra Campus, Obubra, Nigeria \\ Email: benbeff06@yahoo.com
}

Received June 4, 2012; revised July 9, 2012; accepted August 18, 2012

\begin{abstract}
Species richness and human activities in natural environments are among the most important recreational needs. Monthly studies of aquatic fauna, artisanal fisheries and tourism characteristics was conducted during wet and dry seasons, over a two-year period in the three landscapes along the $6817.7 \mathrm{~m}$ length of Agbokum waterfalls by using a close-ended pre-coded survey instrument. Through MANOVA analysis of the 1780 respondents we found strong positive association between peoples visits to the recreational areas and the type of landscape in which the respondents felt happy. People who felt happier in landscape dominated by waterfalls, visit the middle reaches of the river for outdoor recreation more often while people who feel happy in landscapes dominated by slow water current with an extensive wide area and floodplains, visit downstream reaches of the waterfalls more often. Activities performed more often along downstream reaches include fishing, bathing/swimming, boating and hunting while more frequent activities in the middle reaches (waterfalls) include taking photographs, picnics, enjoying nature, outing with family and friends, looking at view, resting and relaxing. A total of 5484 fish representing 22 species belonging to 16 genera from 9 families were sampled with 10 species being restricted to wet season and only 1 in the dry. The number of taxa and individuals present at upstream, midstream and downstream reaches were 16 (2003), 13 (1034), 17 (2447), respectively. Tilapia zillii, Clarias gariepinus and Labeo coubie dominated overall catch constituting 35.5\%. Twenty five operational boats counted during the period of study, were only used downstream by 25 full-time fishermen, 87 part-time, 44 shoreline fishermen and 36 assistant fishermen. Common gears were the hook and line constituting $45.8 \%$, cast and dip net $(10.1 \%)$ bailing $(8.7 \%)$, gill nets $(7.3 \%)$, seine net $(6.4 \%)$ Traps $(5.5 \%)$, lift net $(4.7 \%)$ Dip nets $(0.9 \%)$, poisoning $(2.8 \%)$, cutlass $(3.3 \%)$ and spear $(1 \%)$. Seasonally occurring aquatic fauna include crustaceans (Atya gaboneensis and Palaemon paucidens) (23.5\%) oysters (Etheria elliptica) (15.4\%), clams (Galacea paradoxa) (20.8\%), Manatee (Trichechus senegalensis) (2.5), Hippopotamus amphibious (1.8\%), Otter (Lutra macullicolis) (0.5\%), Crocodyles (Crocodylus niloticus, Crocodylus cataphractus (Aligata) and Osteolaemus tetraspsis) (18.8\%). The nile monitor (Varanus nilaticus), aquatic snake (Anoscopus sp), and three species of water turtle (Kimxys erosa, Pelumedusa sp and Peliosus $s p)(21.6 \%)$. Relatively higher faunal densities and species richness in the upstream and downstream reaches coupled with waterfalls in middle reaches can makes Agbokum waterfalls a tourism destination if only management strategies include Legislation to conserve these natural resources.
\end{abstract}

Keywords: Agbokum Waterfalls; Fishing Activities; Fish Species; Recreational Activities; Landscapes; Aquatic Fauna; Gears

\section{Introduction}

A wide variety of recreational needs have been presented [1-3] and all indicated that recreation in natural environments can bring about a quick and strong recovery in stressed individuals. Findings showed that some particular characteristic of nature are more efficient stress recovery such as species richness [4], broadleafed forest [3], waterfalls and lakes [5] and human activities such as fishing, boating and hunting [6]. Nature-related activities like fishing in natural environment are benefiting to people's health [7]. Waterfalls and fisheries had received very little attention from researchers the world over. In Africa, the reason being that, waterfalls were named after deities and were used as places of traditional and ancestral worships. In other places, the intensity of waterfalls and pressure generated from it due to gravity has given the impression of a lifeless zone [8]. Knowledge of waterfalls systems in Africa are therefore limited to hydrology and geological features $[9,10]$, natural monuments for revenue generation because of their ecotourism potentials especially sport fishing [11]. Artisanal sport fisheries are widely practiced and are the most popular form of outdoor recreational fishing. It provides significant 
social, cultural and economic benefits to man. Sport fishing is a form of small scale-fishery for the fun of it. Simple fishing gears are used, while the catches are designed not to make a living but to concentrate skills for fun. In Africa, a large proportion of both rural and urban populations live along the inland or coastal waters. Examples are Cairo on River Nile, Khartoun at Confluence of blue and white nile, Kampala (Lake Victoria), Kinshasa and Brazaville (River Zarie/Congo), Banjul (River Gambia), Niamey and Bamako (River Niger) and some national capitals located along the coast e.g. Abidjan, Dakar, Rabat, Da Es Salam and Luanda [12]. Settlements close to natural waters offer man's greatest hopes for material supplies and recreation. Delta Lakes in Egypt supply $50 \%$ of annual fish consumption [13]. Large basins in Africa: Niger, Benue, Sokoto, Ouema, Shire, Barotse, Kafu flats, Massili \& Okarango have at least 100 species each [14]. Nigeria offers a wide variety of tourist attraction such as flora and fauna, and agro-tourism, river floodplains and ocean beaches ideal for swimming, sport fisheries and other water sports, wildlife, magnificent waterfalls, vast tracks of tropical rainforest. However, many of these attractions, especially sport fisheries, are still largely untapped, even at their raw state, they still being enjoyed by a few foreign visitors in search of fun. There is need for investors both foreign and local to come and invest in the abundant tourism potential in the country. Improved management of the inland water body must start with good knowledge of water bodies, information on current status of fisheries and socio-economic characteristic of fishing communities. This is expected to provide proper integration of all stakeholders in the management of the resources. Therefore this work will focus on the richness and diversity of Agbokum waterfalls tourism resources, including the climatic conditions, artisanal fisheries resources, the exploitation trends, gear used, the species composition and the socioeconomic status of fishers in the waterfalls, for the benefit of the managers.

\section{Materials and Methods}

\subsection{Study Area}

1) The study area is Agbokim Waterfalls in Cross River State, Nigeria, latitude $5^{\circ} 59^{\prime}$ North and longitude $8^{\circ} 45^{\prime}$ East (Figure 1). It is bounded in the West by the Cross River and in the North by the Cameroon high forests. The climate is the tropical hinter-land type, with wet (May-November) and dry (December-April) seasons. Mean annual temperature ranged between $20^{\circ} \mathrm{C}$ and $32^{\circ} \mathrm{C}$ and annual total average rainfall, from $1450 \mathrm{~mm}$ to 3015 $\mathrm{mm}$. The vegetation is the rainforest type with Soil consisting of deep laterite and dark fertile, clayey and loamy soils. The Agbokim waterfall as most others is a product of two rivers, River Ekim and River Bakue, which are tributaries of the Cross River system. River Ekim is divided into three streams, while River Bakue has four streams. These seven streams flow into a floodplain, from where they independently cascade over steep cliff which provides seven-faced falls into the casket or waterfalls. Of ecological importance are numerous small pools and swamps which are found along the length of the waterfalls. The high annual discharge and rainfall of the area provide excellent buffers against natural ecological stresses such as drought [15]. For the purpose of this study, the $6817.7 \mathrm{~m}$ long waterfall is divided into three landscape types; upstream (agricultural plains), midstream (mountain region and waterfalls) and downstream (forest environment). Upstream is $2003.13 \mathrm{~m}$ long with substrate of gravel and rocks under fast water current and shoreline covered with high forest and cocoa farms, Midstream length of $807.42 \mathrm{~m}$ has substrates of sand and rocks under heavy water turbulence with shoreline sparsely shaded with vegetation while downstream length, $4007.15 \mathrm{~m}$ has fine sand and clay under slow water current with an extensive wide area.

\subsection{Data Collection}

\subsubsection{Public Survey}

The study designed and administered a close-ended precoded instrument to conduct a survey of communities located in the study area. A representative sample of people living in neighboring communities around the Agbokum waterfalls was obtained and they performed the task by sending questionnaires to randomized sample of members of the communities. The questionnaires were sent by hand to randomly selected individuals age 18 to 90 years. A total of 2000 questionnaires were sent and a total of 1780 was completed and returned. The response rate was thus $89 \%$. We associated the respondents' background data concerning addresses with the three main landscape types. An examination of respondents' profiles showed that the distribution of socio-demographic data is representative of the general situation in Agbokum waterfalls communities. This means no significant statistical deviation existed with regards to socio-economic groupings (SES).

\subsubsection{Perceptions of Landscape}

The questionnaire included the questions: Do tourist visit the Agbokum waterfalls?

Which of the landscape do they visit most? Which category of tourist that visit the waterfalls? How often do people visit each of the landscape under the study area? What are the reasons for tourists visit to Agbokim waterfalls? When do tourists visit the waterfalls? What role does government play in the management of the Agbokim waterfalls? What infrastructural facilities are in 


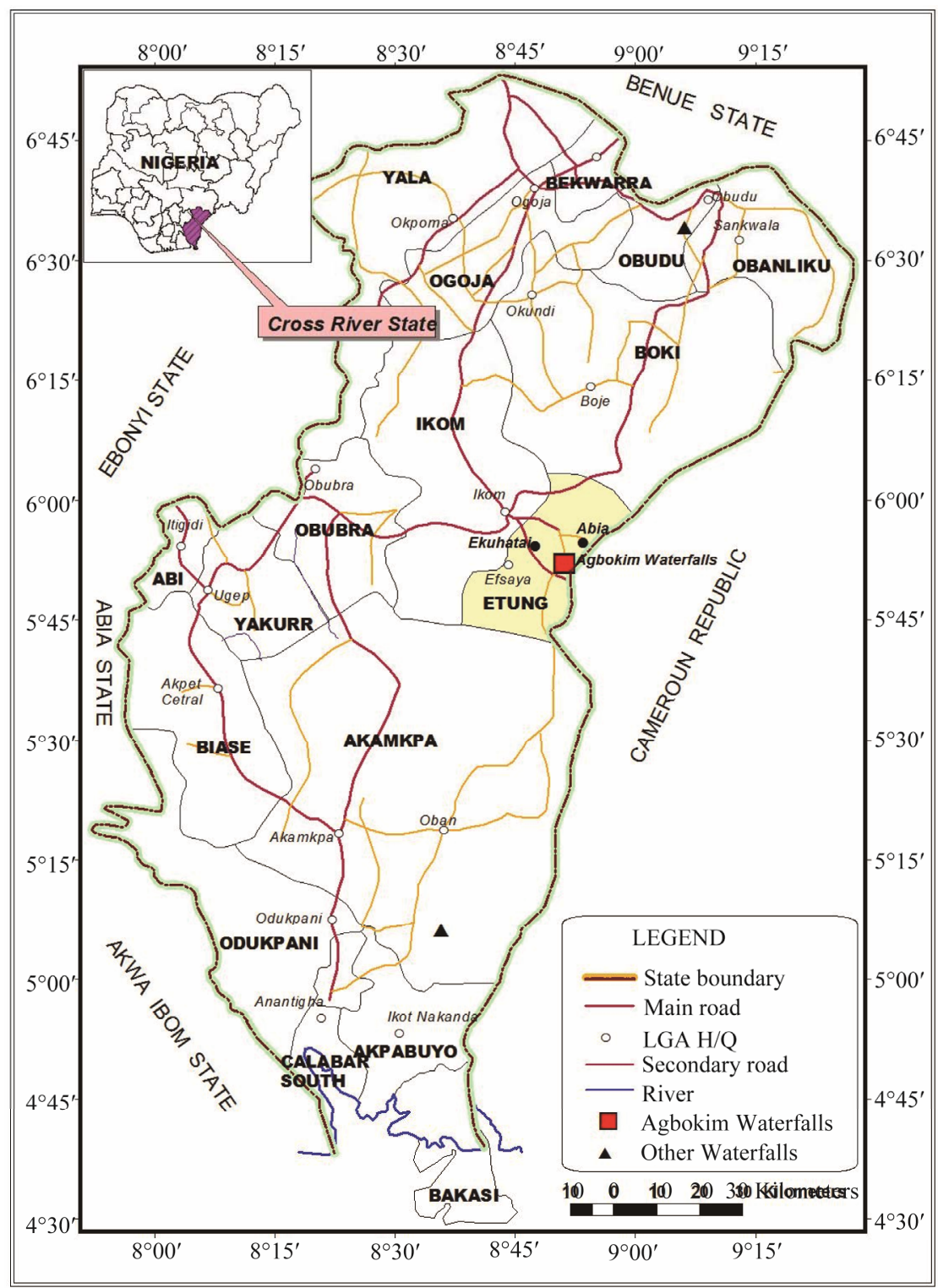

Figure 1. Map of Cross River State showing Agbokim waterfalls.

and around the Agbokim waterfalls? How often do tourist perform a certain outdoor activities (swimming, boating, fishing, hunting)? In which of the landscape do tourists fill most at home? State one or more alternative(s). landscape dominated by 1) Agricultural plains (upper reaches), 2) Forest areas (down reaches), and 3) Waterfalls and mountains (middle reaches). These alternatives correspond to the main landscape types in Agbokum waterfalls. We performed factor analysis (Promax Oblique rotation) to examine whether there was an association between "feeling at home" in these three landscape types. Principal Component Analysis was used to analyzed the data. The respondent answers were statistically analyzed using the statistical software SAS (SAS Statistical, 2009).

\subsubsection{Fisheries Activities}

Frame survey of communities along the $6817.7 \mathrm{~m}$ length was carried out employing the complete census technique [16]. During the survey, existing landing sites, number of fishers, number of canoe units, types of fishing gear and available aquatic mulluscs, mammal and reptiles were enumerated.

Fish species composition and distribution in Agbokum waterfalls were obtained indirectly from earlier work [17]. An estimate of standing stock of fish was made, using the formulae by Henderson and Welcome (1974) as:

$$
\mathrm{S}=\mathrm{B} / \mathrm{A}
$$

which expresses the basic interrelationship between annual catch in wet weight, standing stock size (B) and area 
covered (A). Sum of total fish landings for the 3 reaches gives estimate for the entire river. CPUE $=$ Weight of total harvest/effort level.

Fishing activities = Mean number of operational boats/ day.

Fish abundance $=\mathrm{CPUE} /$ reach .

Data were analyzed using descriptive statistics (mean, standard deviation and percentage). Comparison of data from reaches was carried out using analysis of variance (ANOVA) [18].

\section{Result}

\subsection{Perception of Landscapes}

A MANOVA analysis (SAS GLM) between the landscape the respondent feels happy and how often they visit the three recreational landscapes showed that only two of the natural landscapes were frequently visited for excursions, which were not of the same magnitude. Through MANOVA analysis of the 1780 respondents we found strong positive association between peoples visits to the recreational areas and the type of landscape in which the respondents felt happy. For instance, people who felt happier in landscape dominated by waterfalls, visit the middle reaches of the river for outdoor recreation more often $(\mathrm{p}<$ 0.0001), while people who feel happy in landscapes dominated by slow water current with an extensive wide area and floodplains, visit downstream reaches of the waterfalls more often $(p<0.0001)$. A few respondents with interest in fast water current and shoreline covered with high forest and cocoa farms visit the upper reaches more often $(\mathrm{p}<0.0001)$. The MANOVA test shows an overall effect concerning associations between interest in a certain type of landscape and visits to different types of recreational areas, except for the few people who have interest in fast water current and shoreline covered with high forest and cocoa farms. People's socio-economy did not affect any relationship. However, visiting a "beach/ bathing place" at the waterfalls or downstream reaches was significantly associated with people's gender, and this relationship concerned the midstream and downstream reaches: women visit these recreational areas more often.

\subsection{Out-Door Activities}

A T-test analysis performed between the type of landscape the respondent feels happy and the 12 single activities (outcome) showed that the most frequently performed outdoor activities were fishing, boating, bathing followed by enjoying nature and taking photographs, hunting and outings with family and friends. T-test of respondents who feel happy in landscapes dominated by one landscape type versus people who feel happy in another landscape type showed that activities performed more often in down- stream reaches include fishing ( $p<0.0001)$, bathing/ swimming $(\mathrm{p}<0.001)$, boating $(\mathrm{p}<0.01)$ and hunting $(\mathrm{p}<$ $0.01)$. Activities performed less often include outing with family and friends $(\mathrm{p}<0.001)$, taking photographs $(0.001)$, picnic $(p<0.01)$, enjoying nature $(p<0.01)$ and going out to be myself $(p<0.05)$. Activities performed more often in the middle reaches (waterfalls) include: Taking photographs $(\mathrm{p}<0.0001)$, picnics $(\mathrm{p}<0.0001)$, enjoying nature $(\mathrm{p}<0.001)$, outing with family and friends ( $p<0.001)$, looking at view $(p<0.01)$, resting and relaxing $(\mathrm{p}<0.05)$. Activities performed less often include: fishing $(\mathrm{p}<0.001)$, hunting $(\mathrm{p}<0.01)$, bathing $(\mathrm{p}<$ $0.01)$ and sunbathing $(\mathrm{p}<0.05)$. Activity performed more often in the upper reaches includes: looking at the view $(\mathrm{p}<$ 0.05), Fishing $(\mathrm{p}<0.001)$ (Table 1).

Cluster analysis performed (Varclus disjoint oblique principal component cluster analysis with orthoblique initialization) to find similarities between activities carried out by our respondents (Table 2). All the activities between the people who answered the questionnaire were clustered. The various outdoor activities were merged into different clusters, depending on how often and in what combination they have been implemented by the respondents. These clusters are renamed activity types. The activity types were established using the formula (Activity $1 \ldots$ Activity $n) / n=$ Activity type. The cluster analysis brought together activity with common content. The first cluster contains activities; fishing, boating and hunting which are associated with wild nature: wilderness activities. The second cluster contains of activities in which contact with family members and friends is important: Social activities. The third cluster contains activities: going out to be by myself, photographing, enjoying nature, looking at the view are associated with individual and focused attention: individual experience with nature. The most common activity types were social activities and wilderness activities.

\subsection{Fish Species Composition and Abundance}

A total of 5484 fish representing 22 species belonging to 16 genera from 9 families were sampled during both dry and wet seasons, with 10 species being restricted to wet season and only 1 in the dry, which was of very rare taxa (Table 1). The number of taxa and individuals present at upstream, midstream and downstream reaches were 16 (2003), 13 (1034), 17 (2447) respectively (Table 3). Cichlidae, Clariidae and Cyprinidae were the most abundant families accounting for $56.7 \%$ of the total catch. Tilapia zillii, Clarias gariepinus and Labeo coubie dominated overall catch constituting $35.5 \%$. Five species were site specific because of the association with only the midstream portion of the river (L. senegalensis), upstream (A. gardneri, A. filmentosus and E. sexfasciatus) 
Table 1. Association between performing certain recreational activities and having preference to certain landscape area.

\begin{tabular}{lccc}
\hline Recreational activity & Up-river & Mid-river & Down-river \\
\hline Fishing & $6.7(\mathrm{p}<0.001)$ & $5.6(\mathrm{p}<0.001)$ & $12.4(\mathrm{p}<0.0001)$ \\
Swimming & $1.5(\mathrm{~ns})$ & $1.2(\mathrm{~ns})$ & $17.8(\mathrm{p}<0.0001)$ \\
Bathing & $0.7(\mathrm{~ns})$ & $6.6(\mathrm{p}<0.01)$ & $18.8(\mathrm{p}<0.0001)$ \\
Boating & $1.2(\mathrm{~ns})$ & $1.1(\mathrm{~ns})$ & $10.3(\mathrm{p}<0.01)$ \\
Hunting & $0.7(\mathrm{~ns})$ & $2.8(\mathrm{p}<0.001)$ & $8.5(\mathrm{p}<0.01)$ \\
Enjoying nature & $1.5(\mathrm{~ns})$ & $7.8(\mathrm{p}<0.001)$ & $3.5(\mathrm{p}<0.01)$ \\
Taking photographs & $0.8(\mathrm{~ns})$ & $17.7(\mathrm{p}<0.0001)$ & $4.4(\mathrm{p}<0.001)$ \\
Outing with families and friends & $0.2(\mathrm{~ns})$ & $8.9(\mathrm{p}<0.001)$ & $3.2(\mathrm{p}<0.001)$ \\
Going out to be myself & $0.8(\mathrm{~ns})$ & $1.0(\mathrm{~ns})$ & $4.3(\mathrm{p}<0.05)$ \\
Picnics & $0.2(\mathrm{~ns})$ & $14.4(\mathrm{p}<0.0001)$ & $3.7(\mathrm{p}<0.01)$ \\
Looking at view & $5.4(\mathrm{p}<0.05)$ & $5.6(\mathrm{p}<0.01)$ & $3.0(\mathrm{p}<0.01)$ \\
Resting and relaxing & $1.0(\mathrm{~ns})$ & $7.6(\mathrm{p}<0.05)$ & $1.1(\mathrm{~ns})$ \\
Sun bathing & $0.7(\mathrm{~ns})$ & $3.4(\mathrm{p}<0.05)$ & $1.9(\mathrm{~ns})$ \\
\hline
\end{tabular}

Table 2. Associations between different outdoor activities.

\begin{tabular}{clcc}
\hline Cluster & Variables & Proportion Explained & Interpretation \\
\hline 1 & Fishing, hunting & 56 & Wilderness experience \\
2 & Outgoings with family and friends, resting and relaxing Picnics & 34 & Social activities \\
3 & Sunbathing, bathing & 46 & Sun and bathing \\
4 & Looking at view, boating, Picnics & 60 & Boating and view \\
5 & Taking photographs, Going out to be myself & 76 & Individual experience in nature \\
6 & Enjoying nature, swimming & 45 & Enjoying nature \\
\hline
\end{tabular}

Table 3. Relative proportions of fish species $\left(\mathrm{p}_{\mathrm{i}}\right)$, Shanon-Wiener diversity $\left(\mathrm{H}^{\prime}\right)$ and equitability $(\mathrm{E})$ indices for the three zones (January 2006 to December 2007).

\begin{tabular}{|c|c|c|c|}
\hline Reaches & Up-river & Mid-river & Down-river \\
\hline Family/species & $\mathrm{p}_{\mathrm{i}}$ & $\mathrm{p}_{\mathrm{i}}$ & $\mathrm{p}_{\mathrm{i}}$ \\
\hline \multicolumn{4}{|l|}{ Cichlidae: } \\
\hline Oreochromis niloticus & 0.042 & 0.008 & 0.040 \\
\hline Tilapia zilli & 0.110 & 0.238 & 0.098 \\
\hline Hemichromis fasciatus & 0.000 & 0.000 & 0.011 \\
\hline Pelmatochromis guntheri & 0.010 & 0.006 & 0.024 \\
\hline \multicolumn{4}{|l|}{ Hepsetidae: } \\
\hline Hepsetus odae & 0.022 & 0.008 & 0.006 \\
\hline \multicolumn{4}{|l|}{ Characidae: } \\
\hline Hydrocynus vittatus & 0.012 & 0.004 & 0.005 \\
\hline Alestes nurse & 0.062 & 0.005 & 0.031 \\
\hline Alestes macrocephalus & 0.011 & 0.002 & 0.006 \\
\hline \multicolumn{4}{|l|}{ Distichodontidae: } \\
\hline Distichodus enegycephalus & 0.134 & 0.000 & 0.223 \\
\hline Distichodus rostratus & 0.001 & 0.000 & 0.002 \\
\hline
\end{tabular}


Continued

\begin{tabular}{|c|c|c|c|}
\hline \multicolumn{4}{|l|}{ Clariidae: } \\
\hline Clarias anguillaris & 0.031 & 0.005 & 0.057 \\
\hline Clarias gariepinus & 0.023 & 0.014 & 0.315 \\
\hline Heterobranchus longifilis & 0.000 & 0.000 & 0.111 \\
\hline \multicolumn{4}{|l|}{ Bagridae: } \\
\hline Chrysichthys nigrodigitatus & 0.000 & 0.000 & 0.013 \\
\hline Auchenoglanis occidentalis & 0.000 & 0.000 & 0.003 \\
\hline \multicolumn{4}{|l|}{ Mochokidae: } \\
\hline Synodontis clarias & 0.015 & 0.004 & 0.018 \\
\hline \multicolumn{4}{|l|}{ Cyprinidae: } \\
\hline Labeo coubie & 0.388 & 0.121 & 0.003 \\
\hline Labeo senegalensis & 0.000 & 0.044 & 0.000 \\
\hline Barbus occidentalis & 0.034 & 0.003 & 0.001 \\
\hline \multicolumn{4}{|l|}{ Cyprinodontidae } \\
\hline Aphyosemion gardneri & 0.034 & 0.000 & 0.000 \\
\hline Aphyosemion filamentosum & 0.018 & 0.000 & 0.000 \\
\hline Epiplatys sexfasciatus & 0.110 & 0.000 & 0.000 \\
\hline Mean \pm SD & $1.7 \pm 0.4$ & $0.8 \pm 0.1$ & $1.8 \pm 0.3$ \\
\hline Equitability Index & 0.12 & 0.03 & 0.14 \\
\hline
\end{tabular}

(Ikpi and Offem 2011).

and downstream reaches $(\mathrm{H}$. fasciatus, A. occidentalis and C. nigrodigitatus). Two species occur both midstream and downstream reaches only (D. rostratus and D. engycephalus) and one upstream and downstream $(\mathrm{H}$. longifilis). Distribution of other species revealed no distinct trends.

\subsection{Richness and Diversity Indices}

The Shannon-Weiner diversity index showed significant difference between reaches, with downstream reaches having highest diversity throughout the year (Figure 2). Seasonal differentiation in the diversity indices revealed higher values for the wet season samples than dry season. Table 4 shows values of the diversity function for downstream $(1.8 \pm 0.3$ (F: 2.46, p < 0.05), midstream $(0.8 \pm$ $0.1)$ and upstream $(1.7 \pm 0.3)$. Equitability index $(E)$ was generally low ranging from 0.03 (midstream) to 0.14 (downstream).

\subsection{Aquatic Fauna of Tourist Interest}

Other aquatic fauna of interest to tourist are shown in Table 5. Seasonally occurring fresh water crustaceans, Atya gaboneensis and Palaemon paucidens contributed $23.5 \%$ of the aquatic fauna during dry season. Etheria elliptica, an oyster, represented $15.4 \%$. They occurred in rocky beds near the lowest water level. Many people eat the flesh and during the dry season, smoked mussels were commonly seen in riverside market places. Large

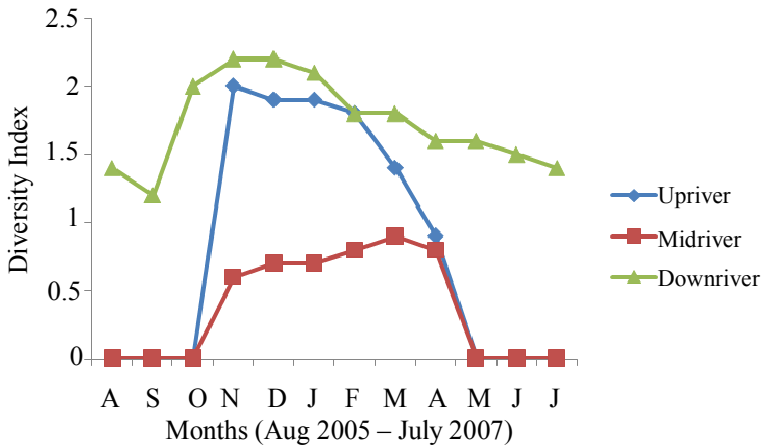

Figure 2. Shanon weanner diversity index for Agbokom water falls (August 2005-July 2007) [17].

middens of empty shells were frequently found near old village sites. A species of fresh water clam, Galacea paradoxa belonging to the family Donacidae was well represented downstream $(20.8 \%)$ and upstream (18.8\%) but absent midstream. Trichechus senegalensis (Manatee) occurred, occasionally, downstream during wet season (flood period), contributing just about 2.5\%. Hippopotamus amphibious (Hippopotamus) have also been reported occasionally from isolated places downstream (1.8\%) but scarce in other reaches $(0.1 \%)$. A species of Otter (Lutra macullicolis) was reported downstream $(0.5 \%)$ during dry season. They were nuisance to fishers using gill nets and asserted traps as they capture fish and destroy the net or traps. Three species of crocodiles; Crocodylus niloticus, Crocodylus cataphractus (Aligata) and Osteolaemus 
Table 4. Seasonal variation in the relative abundance (\%) of fish species in cross river.

\begin{tabular}{|c|c|c|}
\hline Seasons & Wet season & Dry season \\
\hline \multicolumn{3}{|l|}{ Family/species } \\
\hline \multicolumn{3}{|l|}{ Cichlidae: } \\
\hline Oreochromis niloticus & 7.7 & 1.9 \\
\hline Talipia zilli & 2.0 & - \\
\hline Hemichromis fasciatus & 1.9 & - \\
\hline Pelmatochromis guntheri & - & 0.1 \\
\hline \multicolumn{3}{|l|}{ Cyprinodontidae } \\
\hline Aphyosemion gardneri & 1.9 & - \\
\hline Aphyosemion filamentosum & 1.8 & - \\
\hline Epiplatys sexfasciatus & 1.4 & - \\
\hline \multicolumn{3}{|l|}{ Hepsetidae: } \\
\hline Hepsetus odae & 1.0 & 1.6 \\
\hline \multicolumn{3}{|l|}{ Characidae: } \\
\hline Hydrocynus vittatus & 1.8 & - \\
\hline Alestes nurse & 3.0 & - \\
\hline Alestes macrocephalus & 0.7 & 0.6 \\
\hline \multicolumn{3}{|l|}{ Distichodontidae: } \\
\hline Distichodus rostratus & 0.4 & - \\
\hline Distichodus enegycephalus & 0.3 & \\
\hline \multicolumn{3}{|l|}{ Clariidae: } \\
\hline Clarias anguillaris & 5.9 & 2.7 \\
\hline Clarias gariepinus & 3.3 & 1.3 \\
\hline Heterobranchus longifilis & 2.0 & 0.5 \\
\hline \multicolumn{3}{|l|}{ Bagridae: } \\
\hline Chrysichthys nigrodigitatus & 10.4 & 4.3 \\
\hline Auchenoglanis occidentalis & 0.5 & - \\
\hline \multicolumn{3}{|l|}{ Mochokidae: } \\
\hline Synodontis clarias & 2.1 & - \\
\hline \multicolumn{3}{|l|}{ Cyprinidae: } \\
\hline Labeo coubie & 0.9 & 0.4 \\
\hline Labeo senegalensis & 0.5 & 0.5 \\
\hline Labeo parvus & 0.2 & 0.1 \\
\hline
\end{tabular}

[17].

tetraspsis were common downstream (18.8\%) scarce upstream (3.6\%) but absent midstream. The nile monitor, Varanus nilaticus, aquatic snake, Anoscopus sp, and three species of water turtle: Kimxys erosa, Pelumedusa sp and Peliosus sp were common downstream (21.6\%) during rains, occasionally found upstream $(2.8 \%)$ but absent midstream.

\subsection{Fisheries Activities}

Fishing methods were determined by flood regimes (rising flood: May-July, high flood: August-October, receding flood: November-January and recession: FebruaryApril). Rising flood (early wet season) and receding flood (late wet season) regimes were the major fishing periods in the study area. 
Table 5. Relative proportion $\left(\mathrm{p}_{\mathrm{i}}\right)$ of other aquatic fauna of tourist interest in Agbokum waterfalls.

\begin{tabular}{lccc}
\hline Reaches & Upstream & Midstream & Downstream \\
\hline Other aquatic fauna & $\mathrm{p}_{\mathrm{i}}$ & $\mathrm{p}_{\mathrm{i}}$ & $\mathrm{p}_{\mathrm{i}}$ \\
Atya gaboneensis (Crustaceans) & 0.01 & 0.08 & 0.12 \\
Palaemon paucidens (Crustaceans) & 0.06 & 0.04 & 0.15 \\
Etheria elliptica (Oyster) & 0.06 & 0.00 & 0.18 \\
Donacidae & & & 0.18 \\
Galacea paradoxa (Clams) & 0.08 & 0.00 & 0.15 \\
Trichechus senegalensis (Manatee) & 0.00 & 0.00 & 0.18 \\
Hippopotamus amphibious & 0.10 & 0.00 & 0.05 \\
Lutra macullicolis (Otter) & 0.00 & 0.00 & 0.17 \\
Crocodylus niloticus, (Aligata) & 0.08 & 0.00 & 0.13 \\
Crocodylus cataphractus & 0.06 & 0.00 & 0.16 \\
Osteolaemus tetraspsis & 0.01 & 0.00 & 0.13 \\
Varanus nilaticus (Nile monitor) & 0.02 & 0.00 & 0.18 \\
Anoscopus sp (Aquatic snake) & 0.03 & 0.00 & 0.11 \\
Kimxys erosa (Water turtle) & 0.02 & 0.00 & 0.12 \\
Pelumedusa sp & 0.02 & 0.00 & 0.10 \\
Peliosus sp & 0.01 & 0.00 & \\
\hline & & & \\
\end{tabular}

Twenty five operational boats were counted during the period of study (Table 6), which were only used downstream with 25 full-time fishermen, 87 part-time, 44 shoreline fishermen and 36 assistant fishermen. The use of boats were impossible upstream and midstream because of the ecology and geological nature, with 18 parttime fishermen, 33 shoreline fishermen, 22 assistant fishermen and no full-time fishermen in upstream, while midstream had 9 part-time fishermen, 31 shoreline, 11 assistants and no full-time fishermen.

Three major communities lie on the stretch of the waterfalls reaches. Abia had the 84 fishers with 12 canoe units and a total monetary value of five hundred and eighty thousand eight hundred and sixty three naira (N580,863). Agbokum had the least number of fishers (29) with 8 canoe units and total value of one hundred and fifteen thousand five hundred and sixty naira $(\mathrm{N} 115,560)$. Ekuhatai had about 118 fishers with a total of 45 canoe units valued at one million two hundred and seventy thousand two hundred naira $(\mathrm{N} 1,270,200)$. The numbers of fishers in the various reaches are also given in Table 7.

\subsection{Fishing Gear/Methods}

List of gears idenified in the 3 zones is presented in Table 8. Common gears were the hook and line constituting $45.8 \%$, cast and dip net $(10.1 \%)$ bailing $(8.7 \%)$, gill nets (7.3\%), seine net (6.4\%) Traps (5.5\%), lift net $(4.7 \%)$ Dip nets $(0.9 \%)$, poisoning $(2.8 \%)$, cutlass $(3.3 \%)$ and spear (1\%). Different methods of fishing were practiced during different times of the year. Fishing during rising flood (May-July) was dominated by hook and line (59.4\%) of sizes 7 - 11 baited and unbaited No. 12 - 14; monofilament gill nets (31\%) (mesh sizes: $64 \mathrm{~mm}, 76$ $\mathrm{mm}$ and $10 \mathrm{~mm}$ ), seine nets (24.2\%) (mesh size; $76 \mathrm{~mm}$ ). Flood season (August-October) was characterized by abundant hook and line (46.8\%) (sizes; no. 7 - 14 baited and unbaited), $28.8 \%$ traps (mesh size $25.4 \mathrm{~cm}$ ), $24.2 \%$ gill nets (mesh: 58 - $64 \mathrm{~mm}$ ). Receding season had mostly hook and line (16.6\%) (no. $7 \& 13,200$ mts baited 9 , 12 and 16 unbaited), traps (16.4\%), lift nets (14.7\%) (mesh size; $0.5 \mathrm{~mm}$ ), bailing (12.8\%) seine nets $(11.6 \%)$ $(25 \mathrm{~mm}$ mesh size) and gill net $(9.5 \%)(25 \mathrm{~mm} 38 \mathrm{~mm}$ and $76 \mathrm{~mm}$ mesh sizes). Bailing or dewatering form the major fishing method during the recession season $(36.1 \%$ of fishermen), hook and line (16.5\%), falling gears $9.8 \%$, seine nets $(8.7 \%)$ (76 mm mesh size), poisoning $(8.7 \%)$, cutlass $(2.8 \%)$ and spear (1.2\%). Most common gear mesh sizes were 20 - $50 \mathrm{~mm}$ (74).

\section{Discussion}

\subsection{Recreational Landscapes and Activities in Agbokum Waterfalls}

The attachment to a certain type of landscape, including activities relating to that kind of landscape is determined by habits originating from previous life experiences [19]. With the interpretation of our results concerning which 
Table 6. Flood regime, average fishing activities and fish landings in Cross River inland wetlands.

\begin{tabular}{|c|c|c|c|c|}
\hline Months & Boats in operation & Boats sampled & Boats sampled/day & $\begin{array}{c}\text { Catch/boat/day } \\
\mathrm{kg}\end{array}$ \\
\hline $\begin{array}{l}\text { Rising flood } \\
\text { (May-July) }\end{array}$ & 16 & 8 & 4 & 18.4 \\
\hline $\begin{array}{l}\text { High flood } \\
\text { (Aug-October) }\end{array}$ & 5 & 2 & 2 & 1.4 \\
\hline $\begin{array}{l}\text { Receding flood } \\
\text { (Nov-January) }\end{array}$ & 21 & 7 & 3 & 27.7 \\
\hline $\begin{array}{l}\text { Recession } \\
\text { (Feb-April) }\end{array}$ & 8 & 4 & 3 & 8.6 \\
\hline
\end{tabular}

Table 7. Distribution of fishermen in the study area.

\begin{tabular}{|c|c|c|c|c|c|c|}
\hline \multirow{2}{*}{ Study site } & \multicolumn{2}{|c|}{ Full time fishermen } & \multirow{2}{*}{ Part-time fishermen } & \multirow{2}{*}{ Shoreline fishermen } & \multirow{2}{*}{ Assistant fishermen } & \multirow{2}{*}{ Tota } \\
\hline & Boat (non-motorrized) & Boat (motorized) & & & & \\
\hline Upstream & - & - & 18 & 33 & 22 & 73 \\
\hline Midstream & - & - & 9 & 31 & 11 & 51 \\
\hline Downstream & 14 & 11 & 87 & 44 & 36 & 192 \\
\hline
\end{tabular}

Table 8. Percentage and sizes of gear types used in Cross River inland wetlands.

\begin{tabular}{|c|c|c|c|c|}
\hline Gear type & Average No. & Percentage & Mean mesh size (mm) & Mean head line $(\mathrm{m})$ \\
\hline \multicolumn{5}{|l|}{ Gill net: } \\
\hline Set gill net & 27 & 2.1 & 56.8 & 150 \\
\hline Dritting gill net & 9 & 0.9 & 43.5 & 2400 \\
\hline Fixed gill net & 23 & 1.9 & 34.0 & 200 \\
\hline Emcycling gill net & 12 & 1.2 & 21.0 & 350 \\
\hline \multicolumn{5}{|l|}{ Seine nets: } \\
\hline Beach seine net & 25 & 1.8 & 48.0 & 250 \\
\hline Boat seine net & 17 & 0.8 & 56.4 & 250 \\
\hline Lift net (mosquito net) & 20 & 4.7 & 0.5 & $6 \times 6$ \\
\hline \multicolumn{5}{|l|}{ Falling gears: } \\
\hline Cast net & 88 & 9.1 & 10 & 4 \\
\hline Dip net & 13 & 0.9 & 12 & 2 \\
\hline \multicolumn{5}{|l|}{ Traps: } \\
\hline Pots & 54 & 3.2 & 6.0 & 2.5 \\
\hline Fyke nets & 8 & 0.6 & 9.0 & 1.5 \\
\hline Fences & 18 & 1.8 & 10.0 & 100 \\
\hline \multicolumn{5}{|l|}{ Hook and line: } \\
\hline Set longline (baited \&) & 129 & 12.7 & $7-14$ & 50 \\
\hline Drifting long line & 89 & 9.4 & $10-14$ & 200 \\
\hline Hand \& pole & 223 & 23.4 & $12-14$ & 1.5 \\
\hline Bailing (dewatering) & 66 & 8.7 & - & - \\
\hline Poison & 34 & 2.8 & - & - \\
\hline Spear & 12 & 1.2 & - & - \\
\hline Cutlass & 35 & 2.8 & - & - \\
\hline
\end{tabular}


type of the three landscapes in our study area people choose as places of recreation and for recreational activeties is strongly influenced by the environment. The study showed that people who feel at home with a particular type of landscape do visit recreation areas associated with that type of landscape more often. This pattern can possibly be due to the fact that our respondents became attached to this type of nature during their childhood and adolescence. Moreover, our results clearly showed that people who feel at home in a particular type of landscape perform certain outdoor activities more often, which may be because since childhood, have deeper understanding that these activities can be best accomplished there. The result are thus interpreted that people tend to devote themselves to activities associated to where they feel they belong. Our finding support earlier studies $[5,20]$, which maintained that place attachment is an important factor to consider in explaining recreation behavior. Moreover these finding seem to support attachment phenomena connected to old concept of Heimat $[21,22]$. Consequently, whether or not our respondent have moved, feeling at home in a particular type of landscape has importance for their choice of setting and recreational activity. For instance, people who feel at home in the middle and lower reaches of the waterfalls choose bathing and sunbathing. We interpret this as a kind of attachment process $[20,23]$.

Earlier studies suggest that recreation in natural environment restores people from stress [3,24] and the most restorative experience are connected to nature related activities [7]. What the study seem to indicate is that people who live in areas they find correspond with a "feeling at home" seem to have more easy to find places to carry out recreational activities they want to carry out. Our results indicate that activities involving more direct contact with familiar nature area are associated with lower stress levels. Instead the simple and familiar can be interpreted as something secure, something they can trust on and rely on [25]. This knowledge is important to design and plan outdoor areas especially in multicultural communities like ours. The phenomena of feeling at home in a natural environment should be seen as an important factor.

\subsection{Fish Distribution and Abundance}

The 22 fish species 16 genera and nine families recorded in Agbokum waterfalls is higher than 165 species, 97 genera and 41 families identified [26] in Cross River basin and 46 species in 28 genera and 16 families recorded [27] from the three vegetation zones of the Cross River inland wetlands, given the same surface area and volume of water. In the three studies conducted, however, Cichlidae and Cyprinidae appear to be among the most abundant families identified.

Seasonal differentiation evident in higher number of species and individuals caught during wet months of the study period, agree with results of [28] who described larger ichthyofauna densities in water bodies in Grahamstown in the rainy season. Reasons for the variation were ascribed to the connection of the water bodies to the sea which allows free movement of species across the two habitats during flood and these species being able to recruit during flood condition [29]. Agbokim Waterfalls being drained by two small rivers, Ekue and Bakue, which are tributaries of the Cross River system with linkage to Cross River estuary from the lower reaches, could have exhibited the same variation. Also because of the considerable seasonal differences in dissolved oxygen concentration in the system both at low water and during the floods this factor appears to have played an essential role in determining the distribution of fish within the system. In general the more active the species the more it tends to avoid de-oxygenated areas [30]. Most species encountered downstream of the waterfalls during dry season have adaptation for survival in low dissolved oxygen conditions like formation of dormant eggs (Aphyosemion) and presence of external gills (Clarias, Heterobranchus). These species form a group that is well adapted to swamps life and tend to concentrate in the more de-oxygenated small pools and swamps of the floodplain during low water, when other more active species like Tilapia and carp are to be found the midstream (waterfalls) and upstream respectively.

Although on a community basis the three reaches did not separate out, some species when analysed individually revealed specific range preferences. Two heterologous species between two genera, C. gariepinus and L. coubie, the two most common and economically viable benthic fishes, found in this study, demonstrated opposite habitat preference, with $C$. gariepinus dominating the lower reach and L. coubie more abundant in the upper reach. This opposing habitat preference and the attendant ecological and trophic heterogeneity reduces competition, and may be responsible for the overwhelming success of the two species in the Agbokum waterfalls. The relatively higher number of $\mathrm{C}$. gariepinus in the lower reach during this study may be due to the fact that being muddwelling species, most individuals found their natural habitat downriver. The common carp L. coubie adapted to live in shallow rocky bottom assemble in the rocky upriver. Another dominant freshwater species (T. zilli) demonstrated great preference to the turbulent well aerated midstream reaches. This distributional trend, in a similar study [31] was attributed to several factors including fast water current, suitable breeding area, marginal vegetation and the absence of competitors and piscivorous predators. 
The entry into the waterfalls by small stream from the Cameroon forests, has introduced less common species of Aphyosemion filamentosum [32]. Aphyosemion gardneri is the common species in Nigerian waters including the Agbokim waterfalls (Field-survey 2005-2007). Appearance of the new species upriver of the Water Falls has ecological implication on the conservation of the resources of the system. The movement of species between habitats can reduce the rate of local extinction and can also permit re-colonization following local extincttions, which has important implications ranging from population genetics to community composition [33].

Relatively higher fish densities and species richness values in the upstream and downstream reaches, was probably because being mainly forest flood plains, as explained by [34], they offer considerable habitat heterogeneity leading to a large number of potential ecological niches of fish species than the high turbulence nature of midstream especially in the waterfalls region. Therefore, tourist "who feel at home" with recreational activities like fishing will prefer downstream reaches of the waterfalls.

\subsection{Fishing Activities}

25 full-time fishermen with 25 operational boats recorded fell short of 2 full-time fishermen $\mathrm{km}^{-2}$ recommended [23] for optimum catch and viable economic returns for most African inland waters. Agbokum waterfalls with $4.01 \mathrm{~km}^{2}$ downstream should have maximum 8 full-time fishermen. The fishery therefore required reduction of fulltime fishers by 17 fishermen for optimum exploitation. The dominance of the fishery by part-time fishermen (165) who combine fishing with crop farming and therefore practice the profession at subsistence level add more pressure to the fishing intensity.

Dominance of hook and line (46.5\%) as major gear in the study area may be due to low cost price when compared to other gears. Gill net is purchased at between $\mathrm{N} 5000$ to $\mathrm{N} 15,000$ beach seine $(\mathrm{N} 30,000)$, cast net $(\mathrm{N} 10,000)$ while hook and line is between N1500 $\mathrm{N} 2500$. The observation is consistent with findings [35, $36]$ that a large proportion of Nigerian rural dwellers live on margin of subsistence and that majority of the artisanal fishermen are characterized by utilization of low cost craft and gears. Availability of funds is therefore critical factor in gear composition of inland fishery.

Preponderance of obnoxious fishing gears and techniques like gill nets ( $35-62.8 \mathrm{~mm}$ mesh size), lift net $(1.0 \mathrm{~mm})$, casts nets $(5.0-12 \mathrm{~mm})$, traps $(5.0-10 \mathrm{~mm})$, Bailing (dewatering) and poisoning observed during the study did not conform with Federal Legislation (National Decree No 108, 1992) covering inland fisheries in Nigeria [37]. The decree provides in Section 5, sub-section 1.0 that no person shall fish with a gear constructed with net webbing of less than $76 \mathrm{~mm}$. Also that no person shall take or destroy or attempt to take or destroy any fish within the inland waters of Nigeria by any explosive substance, poisonous matter and dewatering. Abiodun [6], showed that $43 \%$ of gill nets, $73 \%$ of drift net, $20 \%$ of cast net nd $100 \%$ beach seine used in Lake Kainji, Nigeria were illegal in accordance with the state fisheries edict. Agbelege et al. [38] observed that dumba (traps of $5 \mathrm{~mm}$ mesh size) fishing can deplete fish rapidly and indiscriminately and juvenile and undersized constitute their catches. Situation where fishing intensity (through use of bad fishing methods) increased during spawning season i.e rising flood (May-July) or immediate postspawning season i.e. receding flood (November-January), as was observed in this study, does not allow recruitment either by massive killing of the young or harvesting of gravid females or pre-spawning population. $[39,40]$ have reported collapse of Labeo stock in two different rivers due to fishing during rising and receding flood in Danube River. Henderson and Welcome [16] observed that sustainability depends on careful balance between fish harvest (mortality) and regenerative capacity (recruitment) of the fish stocks. Upsetting the balance in favour of one of the two factors, they observed, can result in either over-fishing or under-exploitation as was observed in this study.

However unlimited access into the fishery with illegal gears had adversely affected sustainability of the fishery resources. Therefore, management strategies recommended for Agbokum waterfalls include: Legislation against water pollution, control and regulatory measures by community leaders to include: freeing of immature fish captures, obtaining permission from head fishermen before fishing, prohibition of fishing during spawning or immediate post-spawning seasons, mesh size regulation, registration and licensing of fishermen, prohibition of poison and bailing during dry season, management inputs in the form of improved gear and craft, development of fish culture ponds in the floodplains using the network of swamps, lakes and ponds through evolution of appropriate technology for their conversion.

\subsection{Other Aquatic Fauna}

In addition to fish, seasonally occurring fresh water crustaceans, oyster clam, Manatee, Hippopotamus, Otter, crocodiles, aquatic snakes and water turtle in the downstream riches makes the landscape very attractive to game hunting and photographing as recreational activities.

\section{Conclusion}

Relatively higher fish densities and species richness values in the upstream and downstream reaches, makes fishing, game hunting and photographing as the most 
favorable recreational activities of these landscape. The waterfalls middle reaches are for sunbathing, bathing, picnics, Outgoings with family and friends, resting and relaxing. Management strategies to improve tourism potential of Agbokum waterfalls must include: Legislation against water pollution, control and regulatory measures by community leaders to include: freeing of immature fish captures, obtaining permission from head fishermen before fishing, prohibition of fishing during spawning or immediate post-spawning seasons, mesh size regulation, registration and licensing of fishermen, prohibition of poison and bailing during dry season, management inputs in the form of improved gear and craft, development of fish culture ponds in the floodplains using the network of swamps, lakes and ponds through evolution of appropriate technology for their conversion.

\section{REFERENCES}

[1] LCCET, "Landscape Convention Council of Europe Treaty Series No. 176," Council of Europe, Florence, 2000.

[2] M. D. Velarde, G. E. Fry and M. Tveit, "Health Effect of Viewing Landscapes. Landscape Types in Environmental Psychology," Urban Forestry and Urban Greening, Vol. 6, No. 4, 2007, pp. 199-212. doi:10.1016/j.ufug.2007.07.001

[3] M. Annerstedt, J. Norman, M. Boman, L. Mattson, P. Grahn and P. Wahrborg, "Finding Stress Relief in a Forest," Ecological Bulletin, Vol. 53, 2010, pp. 33-44.

[4] P. Grahn and U. K. Stigsdotter, "Landscape Planning and Stress," Urban Forestry and Urban Greening, Vol. 2, No. 1, 2010, pp. 1-18. doi:10.1078/1618-8667-00019

[5] M. J. Gross and G. Brown, “An Empirical Structural Model of Tourists and Places Progressing Involvement and Place Attachment into Tourism," Tourism Management, Vol. 29, No. 6, 2008, pp. 1142-1152. doi:10.1016/j.tourman.2008.02.009

[6] M. Bodin and T. Hartig, "Does the Outdoor Environment Matter for Psychological Restoration Gained through Running?" Psycology of Sports Exercise, Vol. 4, 2003, pp. 141-151. doi:10.1016/S1469-0292(01)00038-3

[7] T. Sugiyama and C. Ward Thompson, “Older People's Health, Outdoor Activity and Supportiveness of Neighborhood," Landscape and Urban Planning, Vol. 83, No. 2-3, 2007, pp. 138-143. doi:10.1016/j.landurbplan.2007.04.002

[8] S. Chernicoff, H. Fox and R. Venkatakrishnan, "Essentials of Geology," Worth Publishers, New York, 1997.

[9] G. Fischer and M. Harris, "Waterfalls of Ontario," Waterfallogy, Vol. 101, 2003. http.//www.startica/user/mharris/waterfallogy.htm/

[10] T. Chester, J. Strong and P. Ayers, "The Waterfalls," 1999. http.//tchester.org/sgm/lists/waterfalls.html

[11] I. A. Ayodele, "An Ecological Basis for the Management of Old Oyo Natrional Park," Ph.D. Thesis, University of
Ibadan, 1988.

[12] FAO (Food and Agricultural Organization), "Inland Fisheries," FAO Technical Guidelines for Responsible Fisheries, No. 6, Rome, 1991.

[13] J. Elkington, "Beware of the Wrath of Dsiris," New Science, Vol. 68, 1975.

[14] R. L. Welcome, "Fisheries Ecology of Flood Plain Rivers," Longman, London, 1985.

[15] G. G. Teugels, G. Reid and R. P. King, "Fishes of the Cross River Basin (Cameroon-Nigeria). Taxonomy, Zoogeograhpy, Musee Royal Del Afrique-Centrale, Tevuren, Belgique,” Annales Sciences Zoologiques, Vol. 260, 1992, pp. 132-137.

[16] N. O. Bankole, O. D. Sule, E. C. Okwundo, I. Omoru, M. Amadi, T. Adeyemo and M. R. Olabanji, "Preliminary Investigation of the Frame and Catch Surveys of Aluu Lakes, Manduguri, Borno State," National Institute of Fresh Water Fisheries Research Annual Report, New Bussa, 1994.

[17] G. U. Ikpi and B. O. Offem, "Fish Composition and Distribution of Tropical Waterfalls in South Eastern Nigeria," Journal of Asian Scientific Research, Vol. 1 No. 6, 2011, pp. 299-311.

[18] R. G. D. Steel and J. H. Torrie, "Principle and Procedures of Statistics," McGraw-Hill, New York, 1980.

[19] J. Bowlby, "Loss: Sadness and Depression," Hogarth Press, London, 1980.

[20] G. Kyle, A. Graefe, R. Manning and J. Bacon, "An Examination of the Relationship between Leisure Activity Involvement and Place Attachment among Hikers along the Appalachain Trail," Journal of Leisure Research, Vol. 35, 2003, pp. 249-256.

[21] C. Applegate, "A Nation of Provincials, the German Idea of Helmat," California, 1990.

[22] P. Blickle, "Heimat. A Critical Theory of the German Idea of Homeland," Rochester, 2004.

[23] A. S. Masten and J. D. Coatsworth, "The Development of Competence in Favourable and Unfavorable Environments. Lesson from Research on Successful Children," American Psycologist, Vol. 53, No. 2, 1998, pp. 205-234. doi:10.1037/0003-066X.53.2.205

[24] T. Hartig, G. W. Evans, L. Jammer, D. Davis and T. Garling, "Tacking Restoration in Urban and Natural Field Settings," Journal and Environmental Psycology, Vol. 23, 2003, pp. 109-123.

[25] P. Grahn, C. T. Ivarsion, U. K. Stigsdotter and I. L. Bengtsson, "Using Affordances as a Health-Promoting Tool in a Therapeutic Garden," In: C. W. Thompson, S. Bell and P. Aspinal, Eds., Inovative Approaches to Researching Landscape and Health, London, 2010.

[26] R. P. King, "Biodiversity of Fresh Water Fishes of the Cross River in the Rain Forest Belt of Cameroon-Nigeria," Proceedings of Workshop, Calabar, Nigeria.

[27] B. O. Offem, Y. Akegbejo-Samsons and T. I. Omoniyi, "Biological Assessment of Oreochromis niloticus Linne: 1958, Pisces: Cichlidae in a Tropical Flood River," African Journal Biotechemistry, Vol. 6, 2007, pp. 1966-1971. 
[28] T. D. Harrison and A. K. Whitefield, "Fish Community Structure in Three Temporarily Open/Closed Estuaries of the Natal Coast," Ichthyololgy, Vol. 64, 1995, pp. 1-58.

[29] P. D. Cowley and A. K. Whitefield, "Ichthyofaunal Characteristics of a Typical Temporarily Open/Closed Estuary in the South-East Coast of South Africa," Ichthyology, Vol. 71, 2001, pp. 1-19.

[30] R. L. Welcomme, "River Fisheries in Africa. The Relationship to Flow Regimes," NAGA, Vol. 26, 1996, pp. 23-25.

[31] A. K. Whitefield and S. J. M. Blaber, "The Distribution of Freshwater Cichlids Sarotherodon assambicus in Estuarine Systems," Environmental Biology Fish, Vol. 4, No. 1, 1979, pp. 77-81. doi:10.1007/BF00005931

[32] D. Mills, G. Vevers and D. G. Campell, "The Golden Encyclopedia of Freshwater Torpical Aquarium Fishes," Golden Press, Western Publishing Company, Wisconsin, 1982.

[33] D. A. Jackson, R. Pedro, P. R. Peres-Neto and J. D. Olden, "What Controls Who Is Where in Freshwater Fish Communities-The Roles of Biotic, Abiotic and Spatial Factors," Canadian Journal of Fisheries and Aquatic Sci- ences, Vol. 58, 2001, pp. 157-170.

[34] E. G. Leigh, "Community Diversity and Environmental Stability: A Re-Examination," Trends in Ecology, Vol. 5, No. 10, 1990, pp. 340-359. doi:10.1016/0169-5347(90)90183-E

[35] L. C. Okere, "Problems Associated with Development of Rural Resources and Potentials," Annual Conference of Nigerian Rural Sociological Association, 1986.

[36] S. Larsson, "Kust-och Flod Fiske Programmeti GuineaBissauen Bakgruids-Beskwing, Gotebarg Fiskeristyreisen," 1984.

[37] B. S. Moses, "Preminary Estimates of Potential Yield of Cross River State Inland Fresh Waster Fisheries," 1981.

[38] O. O. Agbelege, B. A. Omoyeni and U. Aisami, "Barrier (Dumba) Fish Trap in Lake Chad," Implication on the Lake Chad Fishery, 2002.

[39] J. J. Soulsby, "Status of the Lake Mweru Fisher," Fish Research, Vol. 8, 1959, pp. 30-32.

[40] F. D. Sikoki and A. J. T. Otobotekere, "Fisheries in Land of Bayelsa State Central Niger Delta," Port Harcourt, 1999. 